\title{
sciendo
}

DOI: $10.2478 /$ jolace-2021-0002

\section{The need for integration of reading, critical thinking and academic reading skills: a quantitative analysis of Slovak undergraduates' reading performance}

\author{
Jana Javorčíková1, Mária Badinská1, Lenka Ližbetinová ${ }^{2}$ \& David Brett ${ }^{3}$ \\ ${ }^{1}$ Matej Bel University in Banská Bystrica, Slovakia, \\ 2 The Institute of Technology and Business in České Budějovice, Czech Republic, \\ ${ }^{3}$ University of Sassari, Italy \\ jana.javorcikova@umb.sk
}

\begin{abstract}
:
Based on recent research (Alderson, 2005; Khalifa and Weir, 2009), this study focuses on three areas of reading comprehension necessary for a successful academic career: general L2 EFL reading skills, more specific academic reading skills and critical thinking and reading. The study presents an analysis of quantitative research conducted in 2020, based on a sample of Slovak undergraduate students reading an academic text in English as L2 in EFL CLIL-formatted classes in humanities.

The respondents' general reading skills were analysed in the context of their critical reading skills and academic preparedness. When tested for general reading skills, respondents were asked to identify implicit and explicit information and the gist of the text. Academic abilities were tested via the ability to identify the attributes of an academic text, such as the system of references, rational and logical language and causeeffect type of argumentation, which indicated the author and genre of the text. In order to evaluate participants' critical skills with a focus on the social aspects of the text, respondents were asked to identify the importance of the text for themselves and for their community and life. The participants' mean scores and differences in their performances on each task type were compared using descriptive statistics, and multiple analysis of variance. The results suggest that the general reading skills of university undergraduates in Slovakia are adequate, however, more difficulty was encountered with implicit, rather than explicit, tasks. Students also need to improve their critical reading skills and reading for academic purposes. The research outcomes highlight the need to hone the education of future linguists to the new needs of a more text-based society.
\end{abstract}

Key words: academic reading skills, critical thinking, motivation, reading comprehension, reading performance

\section{Introduction}

The nature of general reading, as well as academic reading, has significantly changed over the last decades (UNESCO, 2000, PISA, 2018). The development of the internet, globalisation and the recent pandemic have shifted many in-class text-based instructions and reading assignments to the online environment and also increased the amount of written instructions and texts. Readers, including university students, read more intensively, thus, it is necessary to adjust their reading skills to new circumstances. SWOT analysis is, therefore, essential in order to plan the extent, pace and procedure for necessary future adjustments. In this study, we focused on the analysis of the general reading skills of adult readers (first year university undergraduates) in the English language, their academic reading skills and their critical thinking skills, as well as the necessity to combine all of these in order to excel academically in the increasingly textbased, globalised and internalised world of academia. 


\section{The interrelation of reading, critical reading and academic reading skills: definitions and theoretical approaches}

Reading is for many experts the most essential language skill required by L2 EFL students for academic achievement (Ostler, 1980; Robertson, 1983; McDonough \& Shaw, 1993; Javorčíková \& Kováč, 2017). Recent research into reading (O’Malley et al., 1985; Alderson, 2005; Khalifa and Weir, 2009) has moved away from the traditional behavioural "bottom-up" approach (understanding reading as a teacher-directed isolated skill, processed from the meaning of words and sentences to the overall meaning of the whole unit) towards a more holistic, cognitive approach (understanding reading as studentcentred and learner-driven process where the learner constructs the meaning or meanings via "top-down" methods back to sentence and word-level), especially when reading extensively. The cognitive approach views reading as a hierarchical complex of skills, sub-skills and strategies. This hierarchy of skills was divided by Khalifa and Weir (2009) into cognitive (involving mental manipulation or transformation of materials or tasks, intended to enhance comprehension, acquisition and retention) (O'Malley \& Chamot, 1990), and metacognitive (focused on global meaning and using higher level or processing, such as summarising, previewing, predicting, skimming and search reading) strategies (Piršl, Popovska \& Stojković, 2017). Carrell (1989) recognizes a similar taxonomy of strategies. However, he divides them into local (text-oriented strategies concerned with syntax, lexicon, etc.) and global (focused on "text at large" - the gist of the text, its organization, etc.). The original cognitive and metacognitive strategies were further amended by the phenomenon of so-called "social mediation"; i.e. social or affective strategies, which employ interaction with other people or ideational control over tasks (O'Malley et al., 1985; Khalifa and Weir, 2009)

According to recent research (Cameron 2001; Grabe \& Stoller 2011; Lojová \& Straková 2012; Šipošová 2017), the cognitive approach to reading, and especially to academic reading and reading at professional level, shifts towards a psychological understanding of reading as a broader set of processes that go far beyond the mere recognition of words and utterances, and even beyond understanding relationships in sentences and larger units, such as text and context. A cognitive-psychological model of reading recognizes reading as a complex of hierarchical and multilayered and multicomponent, dynamically changing set of psychological processes (Zápotočná, 2001, p. 1). Modern definitions of advanced reading also take into consideration:

a) Integration of previous linguistic knowledge, skills and experience. These are of key importance, especially in EFL reading, when readers often use skills acquired in their mother tongue (Straková \& Cimermanová 2005, p. 21). Alderson calls the point where reading skills from the mother tongue are translated into reading skills in the foreign language a "language threshold" (Alderson, 2005).

b) Focus on the personality of the reader. Oxford (1990) and Veverková (2020), for example, analyse meta-cognitive (reader-related) reading strategies.

c) Focus on social and critical aspects of reading: Alderson (2005) states that reading also implies understanding the broad meaning of the text, the direct and indirect intentions of the writer, the identification of the assumed writer, and also complementation of the significance of the text for an individual and his or her community. Scholes (1991) and Gavora (2012) also point out the complex social nature of reading and its immediate connection to the life of the reader. Successful readers do not only read, they also integrate reading contents into their actions and thoughts. In this respect, academic reading in the broad sense of the term integrates the methods of social mediation and borrows strategies from critical reading. 
Critical thinking is reasonable and reflective thinking focused on deciding what to believe or do (Ennis, 2001, p. 1). Paul (2006) holds that “...critical thinking is the art about thinking in an intellectually disciplined manner. [Critical thinkers and readers, note: the authors] analyse thinking, they assess thinking, and they improve thinking, and these skills are based on understanding eight elements of thoughts: purpose, key questions, information, concepts and assumptions, implications and consequence, point of view, interpretation and conclusion (Paul \& Elder, 1996). In order to achieve the aforementioned elements of thoughts, specific critical reading skills generally utilise the ability to employ reason, read actively, ask questions before, during and after reading, integrate information and previously acquired knowledge, seek a broader picture of presented information, and generally employ a broad complex of skills, including observation, analysis, interpretation, reflection, evaluation, inference, explanation, problem solving, and decision making (Lipman, 1988; Skills you need, 2020).

On the other hand, academic skills represent a collection of study habits, learning strategies, and time management tools that help students learn and absorb school lessons (Upson, 2021). They are of key importance in five core subjects (language or languages studies, including reading and writing; mathematics; science; history; and technological literacy), giving students the tools they need to assimilate the key lessons of each discipline (Upson, 2021). Ostler (1980), Roberts (1983) and McDonough \& Shaw (1993) assume that among these, academic reading skills are dominant; they translate into all the other core skills. According to many scholars, inspired by Robinson (1948), academic reading skills include: a) surveying (anticipation of the contents based on the heading, sub-heading, afterword, etc.) and the constant asking of questions, creating paragraph headings; b) reading and writing down notes; c) recalling contents and d) reviewing and creating the mental picture of the whole. Recent research by MacLachlan and Reid (1994, pp. 3-4) further expanded Robinson's processes involved in reading and suggests four types of "interpretive framing", essential in order to understand reading contents in academic reading:

1. Extratextual framing-using information outside the text, readers' background knowledge and experience, to understand texts.

2. Intratextual framing-making use of cues from the text, such as headings and subheadings and referential words such as "this" and "that" to understand texts.

3. Intertextual framing-making connections with other texts readers are reading to help to understand the current text.

4. Circumtextual framing-using information from the cover of the book, title, abstract, references, etc. to understand the text.

For adult users reading for academic purposes is therefore a synthetic skill; it uses and combines many of the aforementioned techniques, strategies and sub-skills of general and academic, as well as critical, reading; especially in CLIL-formatted classes, such as university courses on literature, cultural studies and certain aspects of linguistics classes (Höhn, 2020). Moreover, in L2 EFL classes, reading not only integrates processes of critical thinking; general reading becomes critical reading, a new reading style or, a new "lifestyle" (Cottrell 2005, p. 77; Paul, 2006; Kolečáni-Lenčová, 2020). Fig. 1 shows the interconnection of general reading, academic reading and critical reading sub-skills: 


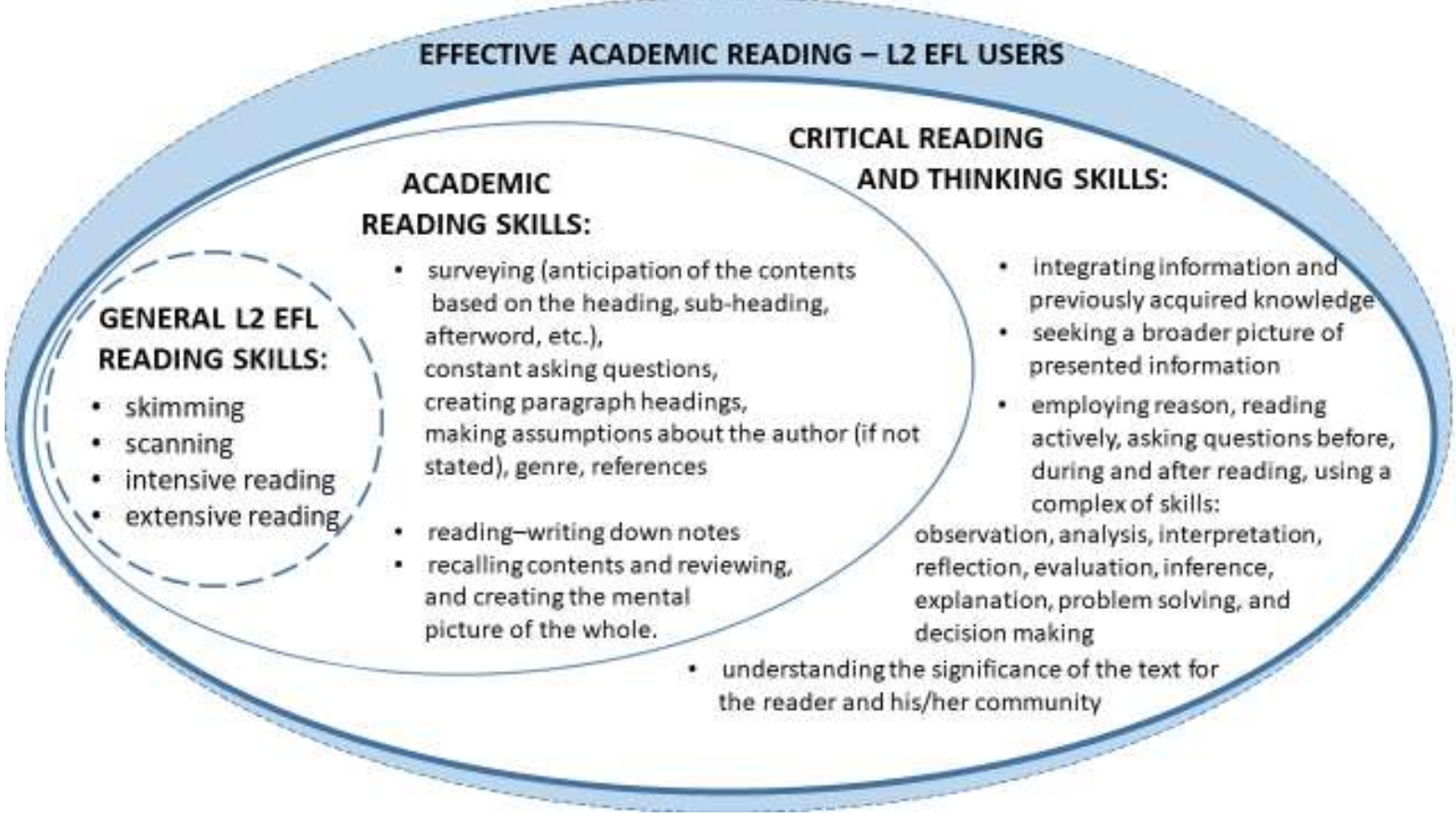

Fig. 1: Integration of general reading, academic reading and critical reading sub-skills for reading in English in CLIL-formatted classes (author: J. Javorčíková)

Conclusively, reading at university level for L2 EFL students is an integrated hierarchical skill with a complex taxonomy of sub-skills, borrowing from academic reading and critical reading and thinking. New ways with text also bring new challenges to advanced EFL learners. In order to excel in their university studies and in an increasingly internationalized learning environment, students are expected to master not only reading in a foreign language (including understanding text and context and its social aspects) but also gain to a good command of academic reading skills (including identification of basic attributes of academic texts, their language and form or argumentation) and critical reading skills (identification of the context, including understanding a broader meaning of the text for the reader and his or her community).

\section{Statement of the problem}

Despite reading comprehension at advanced level being a well-elaborated topic internationally, little similar research has been conducted nationally on the complex reading skills of L2 EFL adult language users, even though it is essential to identify the level of reading comprehension in the very early phase of undergraduate studies in order to detect reading problems that could hinder individuals from succeeding academically. This research constitutes an attempt to explore the way L2 undergraduate students understand three different aspects of an unknown English academic (expository argumentative) text: general L2 reading, academic reading and critical/social reading. To this end, the following research questions will be investigated in this study:

1. Is there any significant difference among undergraduate students reading for explicit and implicit information?

2. Do undergraduate students possess adequate academic reading skills?

3. Can undergraduate students read and understand social aspects of the text (its relevance for their present and future life and career, for their community)? 


\section{Sample unit description, research tools and instrumentation} 3.1 Sample unit description

The holistic approach to effective reading served as a starting point for a quantitative study, conducted in September 2020. ${ }^{1}$ In order to identify their strengths and weaknesses in reading and critical thinking, reading tests were administered to $1791^{\text {st }}$-year full-time undergraduates studying English teaching and translation studies at Matej Bel University, Slovakia. ${ }^{2}$ After stratified random sampling, securing a representative sample of $1^{\text {st }}$ year students, the sample unit was created of 100 valid tests (50 teaching programme and 50 translation studies students). In terms of their declared English level, obtained during the final high school exam (Maturita, equivalent to A-levels), 72 respondents achieved the optimal CEFR B2 level, however, other levels were also recorded in the sample (B1-14 respondents, C1-13 respondents and Maturity exam in Spanish language-1 respondent). The average time of studying English was 11.81 years. 99 respondents were Slovak, one student was bilingual (Slovak and Italian).

\subsection{Research tools, methodology and procedure}

In order to test reading competence, a series of reading skills, critical thinking and academic skills were tested via an extract from a quasi-academic B2-level English text entitled Children, teenagers, and e-books: young people and the new technology. ${ }^{3}$ The text was analogous to standardized Maturita texts for reading comprehension; it contained 509 words, 5 paragraphs, 33 lines, 25 statements and 1 interrogative. Participants took the test in one session.

Reading comprehension was tested by way of 15 questions:

- 9 questions focused on the identification of general reading skills $(Q 1,2,3,6-$ identification of explicitly mentioned information, Q4, 7, 8, 10-implicit answers and Q5- identification of the main idea). These questions were followed by four multiple choice statements (a score of 1 was given for each correct response and 0 for each incorrect response). The mean scores, and differences in participants' performances on each task type were compared using descriptive statistics, and multiple analysis of variance. The results suggest that general reading skills of university undergraduates in Slovakia are adequate, however, more difficulty was encountered with implicit, rather than explicit, tasks.

- 6 questions were academic reading skills $(\mathrm{Q} 12,13,14)$ and critical thinking identifiers $(Q 9,11,15)$. As critical reading often does not invite a single answer, these questions were followed by four multiple choice statements (a score of 1 was given for each correct response and 0 for each incorrect response) but participants could also provide their own answers and commentary in the space provided. The mean scores, and differences in participants' performances on each task type were compared, however, attention was also paid to individual answers, including the incorrect ones.

The length of the text and the test format was selected as a representative of the types of texts students most often read in their undergraduate studies, such as seminar reading

1 Pilot-tests were conducted at the Department of English and American Studies, Matej Bel University, in December 2019; 20 respondents.

266 Slovak respondents were discarded (on the basis of incomplete information, respondents with reading or uncorrected optical disabilities, etc.). Respondents who were familiar with the topic beyond general awareness were not included in the sample unit. 20 international respondents were also discarded; a comparative analysis will be a subject to a study published in 2021.

3 The text was published in a coursebook English File, Upper-intermediate (Oxenden, Latham-Koenig and Seligson 2001; CEFR B2 level); however, the researchers adapted minor details for research purposes. 
logs, assignment criteria, secondary sources, etc.). ${ }^{4}$ The central topic of the text (reading and book-purchasing habits of four different age groups and their preferred print or electronic media) was selected on the assumption that the topic might be familiar to students of humanities (future teachers and translators/interpreters). On the other hand, none of the respondents were experts on the topic, therefore no-one was at an advantage with respect to the other respondents.

\section{Research results}

Table 1 shows the research results of the whole sample (100 respondents).

Tab. 1: Total results: whole sample

\begin{tabular}{|c|c|c|c|c|c|c|}
\hline Mean & $\mathbf{N}$ & $\begin{array}{c}\text { Std. } \\
\text { Deviation }\end{array}$ & Std. Error of Mean & Minimum & Maximum & Median \\
\hline 11.87 & 100 & 1.426 & 0.143 & 8 & 14 & 12.00 \\
\hline
\end{tabular}

Source: authors

Regarding the first part of the research, the mean score for the whole sample was 11.87 points, (median=12; SD =1.426); variance 0.05 . The minimum score was $8(53.33 \%)$, the maximum was 14 points $(93.33 \%)$. The results were not normally distributed. Figure 2 shows the histogram of total sample results.

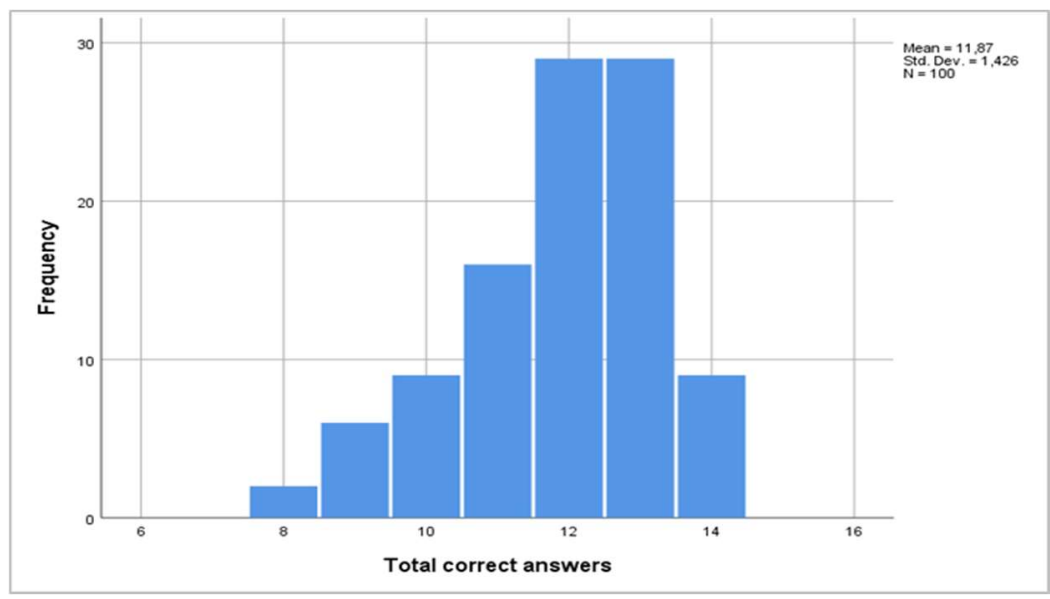

Fig. 2: Total correct answers: whole sample (based on the Kolmogorov-Smirnovov and Shapiro-Wilkov tests of normality, the results are not normally distributed).

\subsection{General reading skills: explicit, implicit information and reading for gist}

General reading skills (reading for implicit, explicit information and reading for gist) were tested by way of 9 comprehension questions and multiple choice answers. The performance of the subjects was scored; a score of 1 was given for each correct response and 0 for each incorrect response. The respondents' mean scores, and differences in their performances on each task type were compared using descriptive statistics, and multiple analysis of variance. In order to measure respondents' general reading comprehension, four questions were related to the identification of explicit information $(Q 4,7,8$ and 10),

4 The authors decided against utilising authentic texts as academic terminology classifies the text as C1, which is required at the Master's level of the respondents' studies. 
another four to identification of implicit information (Q1, 2, 3 and 6) and finally, one to understanding the main idea of the text (Q5). Table 2 shows total L2 reading skills results.

\begin{tabular}{|c|c|c|}
\hline $\begin{array}{l}\text { Reading skills } \\
\text { and sub-skills }\end{array}$ & Descriptors & $\begin{array}{c}\text { Correct } \\
\text { answers } \\
(\%)\end{array}$ \\
\hline \multirow{4}{*}{$\begin{array}{l}\text { Identification of } \\
\text { explicit } \\
\text { information }\end{array}$} & Q 4: How many children own a smartphone acc. to the survey? & 97 \\
\hline & Q 7: Why do teenagers not consider e-books to be social media? & 94 \\
\hline & Q 8: Parents prefer... & 90 \\
\hline & $\begin{array}{l}\text { Q 10: According to the text, how many books are bought } \\
\text { spontaneously? }\end{array}$ & 97 \\
\hline \multirow{4}{*}{$\begin{array}{l}\text { Identification of } \\
\text { implicit } \\
\text { information }\end{array}$} & $\begin{array}{l}\text { Q 1: According to the text, how many young people prefer } \\
\text { printed books to e-books? }\end{array}$ & 80 \\
\hline & Q 2: Teenagers nowadays most often read... & 85 \\
\hline & $\begin{array}{l}\text { Q 3: For whom is the visual and tactile attractiveness of books } \\
\text { most important? }\end{array}$ & 91 \\
\hline & $\begin{array}{l}\text { Q 6: According to the text, which group of readers is the least } \\
\text { interested in e-books? }\end{array}$ & 50 \\
\hline $\begin{array}{l}\text { Understanding } \\
\text { the main idea of } \\
\text { the text }\end{array}$ & Q 5: Who benefits from this type of research and why? & 88 \\
\hline
\end{tabular}

Tab. 2: Total research results: L2 reading skills: explicit, implicit information and reading for gist

Table 2 shows that respondents scored very high in identification of explicit information (Q4, 7, 8 and 10) as the mean score for this skill was 94.5\%. The mean score for identification of implicit information (Q1, 2, 3 and 6) was lower-76.5\%. Interestingly, 50 $\%$ of respondents provided incorrect answers to Q6, despite there being enough textual signals to identify the explicitly stated information, incorrectly assuming the elderly and very little children would be the generation avoiding e-literature (line 21). The difference between implicit and explicit questions is illustrated in Fig. 3.

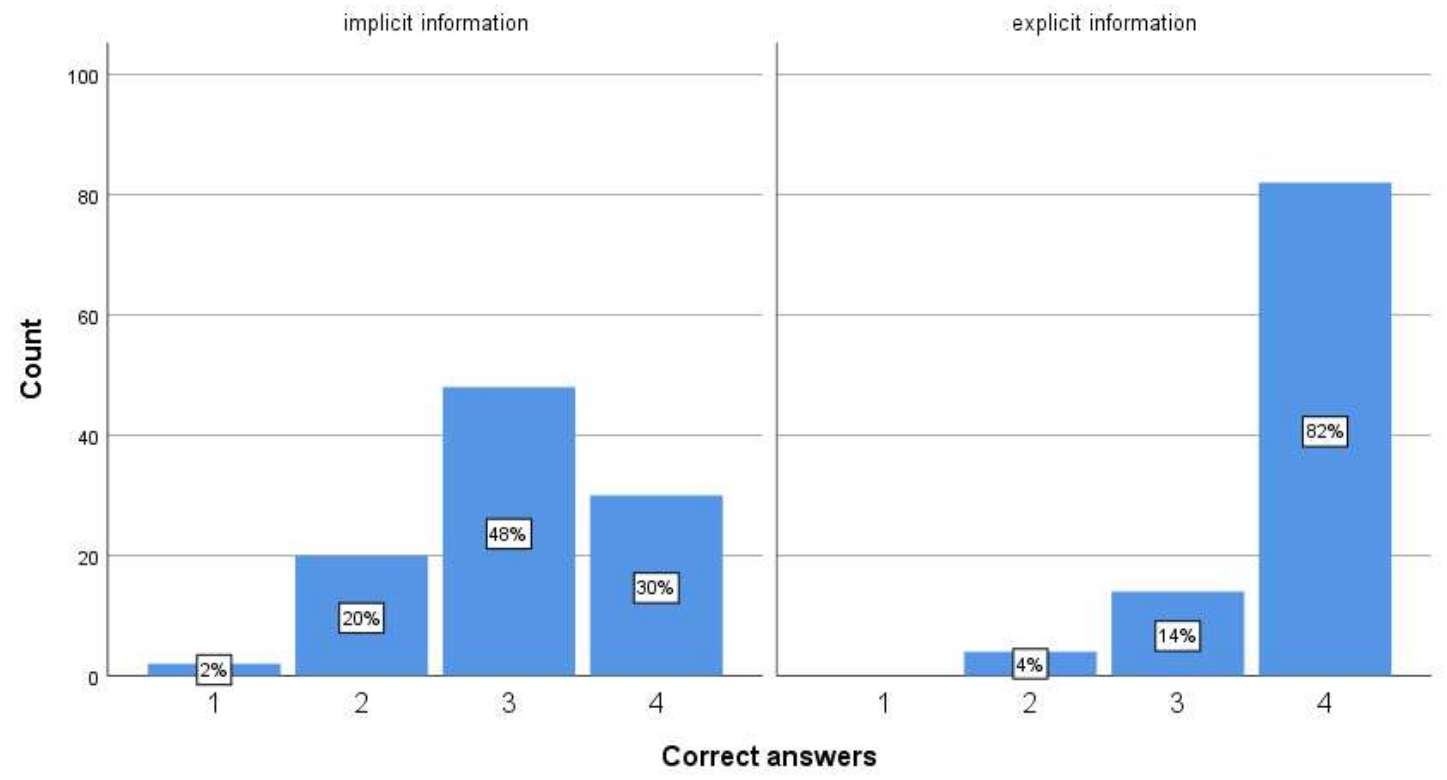

Fig. 3: Correct answers: implicit and explicit questions 
The bar chart (Fig. 3) shows that in terms of implicit questions, correct answers in $98 \%$ spanned from 2 to 4 correct answers, with the most numerous group consisting of students who did not respond correctly only to one question and gained three points. Unlike implicit questions, explicit ones were easily answered by $82 \%$, with minimal representation of students who gained zero or only one correct answer.

\begin{tabular}{|c|c|c|c|c|c|}
\hline & & $\mathbf{N}$ & Mean & $\begin{array}{c}\text { Std. } \\
\text { Deviation }\end{array}$ & $\begin{array}{c}\text { Std. Error } \\
\text { Mean }\end{array}$ \\
\hline \multirow[t]{2}{*}{ IM a EX } & $\begin{array}{l}\text { Implicit } \\
\text { questions }\end{array}$ & 100 & 3,06 & ,763 & ,076 \\
\hline & $\begin{array}{l}\text { Explicit } \\
\text { questions }\end{array}$ & 100 & 3,78 & ,504 & ,050 \\
\hline
\end{tabular}

Table 3: Explicit and implicit information: group statistics

The research results were analysed for normality using the Kolmogorov-Smirnov test; without normal division. According to the Student's t-test, there is a significant difference in the results of these two groups of issues (identification of explicit and implicit information) at a significance level of $1 \%$. Due to abnormal distribution, we verified the ttest using the Mann-Whitney test, which also confirmed significant differences in both issues at significance level 1\%. Slovak undergraduates thus find reading for implicit information more difficult than reading for explicit information. As many as eighty-eight percent were able to grasp the main idea of the text; the overall mean score in general reading tasks, including reading for gist, reading for explicit and implicit information, was $86.33 \%$, which exceeds the student retention number in this course $(81.56 \%)$.

\subsection{Academic reading skills and critical thinking skills}

Apart from general reading skills, six questions were administered to test undergraduates' academic reading skills combined with their critical thinking. These questions included identification of the organization of the text (Q9-identification of the number of sources quoted in the text) and making assumptions about the author and text genre $(Q 11,15)$. Two questions $(Q 12,14)$ were aimed at undergraduates' social strategies (social mediation) as defined by O'Malley (1985) and Alderson (2005)-identification of the importance of the text for students' life and future career (Q14) and understanding the importance of the text (Q12), as well as understanding the general importance of the topic in today's world (Q13). In testing undergraduates' academic reading skills and critical thinking, a slightly different approach was selected; apart from providing multiple choice pre-selected options, students were encouraged to add their own comments, select more options or withdraw from these, if they felt the answers provided did not interpret the text accurately. Only one student indicated more than one option (however, being an international student, he was not included in this study) and no Slovak student included in this study commented on the answers provided or produced his or her own answer. That could indicate the respondents were intimidated by the test; they did not dare to question the options even though they were encouraged to.

\subsubsection{Total results: academic reading and critical thinking (organization and assumptions about the text)}

The reading of academic texts involves various skills, employing four types of framing (intertextual, extratextual, intratextual and circumtextual; MacLachlan \& Reid, 1994, pp. 3-4), which are defined in the theoretical part of this study. Following MacLachlan and 
Reid, we selected three questions, integrating various aspects of academic skills: identification of the genre of the text (based on multiple textual signs, such as academic language, etc.), author (who was not stated, so the readers were to make assumptions about his or her authority in the field, etc.) and type and number of sources referred to in the text, in order to gauge the reliability and relevance of the text. In these questions, the testing procedure was slightly different from the testing of general reading skills; the respondents were instructed to choose one of the options or provide their own answers. Table 4 displays research results in respondents' academic and critical reading skills.

\begin{tabular}{|l|l|c|}
\hline $\begin{array}{c}\text { Academic and critical } \\
\text { reading skills }\end{array}$ & \multicolumn{1}{|c|}{ Descriptors } & $\begin{array}{c}\text { Correct } \\
\text { answers } \\
\text { (\%) }\end{array}$ \\
\hline Organization of the text & Q 9: How many sources were quoted in the text? & 75 \\
\hline Organization of the text & Q 11: The author of the text is... & 73 \\
\hline Organization of the text & Q 15: The genre of the text is... & 83 \\
\hline
\end{tabular}

Tab. 4: Respondents' academic and critical reading skills

Table 4 shows group results of the sample unit. In Q9, only $75 \%$ of respondents were able to identify the correct number of sources (two) based on in-text references and discursive markers. While the text did not feature a bibliography, there were six references in the text, referring to the number of sources quoted (the first survey, a second online survey, $66 \%$ of young adults in the survey said that..., the research showed that..., surveys like these and summatively in line 33: ...the two surveys...). In spite of this, $25 \%$ of the respondents were not able to identify the correct number of sources the author was referring to. Possible reasons for this relatively high number of incorrect answers might be low academic preparedness of graduates (lack of familiarity with the term "survey" and inability to decode linking words the first, second, both and plural surveys). The reasons may also lie in their low academic reading skills; alternatively also in their low ability to identify indirectly mentioned information.

Q11 (potential author) and Q15 (potential genre) focussed on the respondents' ability to make assumptions about the text, its genre and author, even though these are not explicitly stated in the text. ${ }^{5}$ The genre of the text (Q15) was extensively indicated by its neutral style, academic vocabulary, causative argumentation, terminology and many other phenomena (Mistrík, 1997). The potential author was also indicated by the aforementioned references to the genre of the text which categorized him or her as a scholar or a researcher in the respective field.

All the respondents had already passed the Maturita exam and had taken the course Introduction to Linguistics so they were acquainted with basic styles (expository, descriptive, persuasive, argumentative and narrative), as well as with the attributes of an academic text. Also, being in the $1^{\text {st }}$ year of their studies, they had taken 6-10 academic subjects in English in which they were periodically exposed to academic texts and discourse for a minimum of 3 months. Thus, they were expected to be able to identify basic academic text attributes, such as academic vocabulary, precise facts and figures, the referencing system, complex grammar structures, passive structures and cautiontentative language (Mistrík, 1997; Gura, 2005) and, consequently, the assumed author.

\footnotetext{
5 The researchers were aware of the fact that academic texts state the author and references, however, we were interested in participants' ability to detect the missing parts of the academic text, based on their awareness of basic expository argumentative texts.
} 
While the 83\% correct answers in Q15 can be considered high, it is interesting to examine the answers of the $17 \%$ of undergraduates who failed to identify the correct genre. Specifically, 5\% of respondents considered the text to be an extract from an economic report, $10 \%$ of respondents identified it as an extract from a popular informative article and $2 \%$ of respondents considered it to be an extract from an essay. With regards to the fact the genre of the text was indirectly indicated in line 3 (...market research is carried out in this age group on regular basis...) and the fact that students had followed a course focussing on various genres and styles, we find it perplexing that $10 \%$ of the students judged the text to be an extract from a popular informative article and $2 \%$ students deemed it to be an essay. The $5 \%$ of respondents who identified the text as an extract from an economic report were technically right; however, they overlooked the title and subtitle; which are not typical for economic reports.

The respondents were even less successful with the identification of the assumed author of the text in Q11 (73\% correct answers). In response to the assumed author, 20\% of respondents chose the distractor $\mathrm{C}$ (the author of the text is a researcher in adolescent literacy) in spite of the fact that the entire text analysed reading and shopping habits of as many as three groups of readers, not just one: children, teenagers, and also of their parents). Respondents were also reminded of the multiple research focus of the author by the title Children, teenagers and e-books. Also, the text did not relate to literacy in general but to reading habits and preference of e-literature to traditional printed sources by three groups of readers. Six percent of respondents selected distractor A (an educator) in spite of the fact that the article did not refer to any specific subject or teaching process and the reader was several times reminded of the connection of the topic with book markets (line 22-young adult market; line 33-latest trends in the market; line 34-In the case of the children's and young adult market, the two surveys have shown that printed books ... against $e$-books). One respondent selected the distractor B (An owner of a digital device store). Technically, the research could have been conducted for the professional bookselling marketing, but even in that case, the study would have been developed by a researcher, not the owner of a store; thus, the answer was incorrect.

\subsubsection{Reading and social mediation: the significance of the text}

Except for the academic attributes of the text, the set of three questions (Q12, 13 and 14) was designed in order to focus on the broader and social aspect of reading, i.e. understanding the significance of the text for the reader and his or her community. Especially in literature classes and cultural studies classes, students should develop awareness of social mediation, i.e. social aspects of reading (as suggested by 0'Malley, 1985 and Alderson, 2005) and continue in improving their skills in this area as successful reading and academic reading in many aspects overlaps with critical reading skills and relates to the students' personal and professional life. Table 5 shows respondents' critical reading skills in the context of social mediation.

The researchers first analysed the respondents' ability to identify the significance of the text based on intratextual information. Q12 was a synthetic type of question. Respondents were to critically evaluate the importance of the text, based on intratextual information, for themselves and their community. Then, they were to evaluate the significance of the topic in general. Furthermore, students were informed that they can add their commentary to the pre-selected options, select more options or withdraw from these, if they felt the options do not reflect the true value of the text. 


\begin{tabular}{|l|l|c|}
\hline \multicolumn{1}{|c|}{$\begin{array}{c}\text { Academic/critical reading } \\
\text { skills }\end{array}$} & \begin{tabular}{c}
\multicolumn{1}{c|}{ Descriptors } \\
answers \\
(\%)
\end{tabular} \\
\hline $\begin{array}{l}\text { Understanding the importance } \\
\text { of the text for the reader's } \\
\text { community }\end{array}$ & Q 12: This text is important because... & 12 \\
\hline $\begin{array}{l}\text { Understanding the general } \\
\text { importance of the topic }\end{array}$ & $\begin{array}{l}\text { Q 13: This topic is generally important } \\
\text { nowadays. }\end{array}$ & 100 \\
\hline $\begin{array}{l}\text { Understanding the importance } \\
\text { of the text for the life of the } \\
\text { reader }\end{array}$ & $\begin{array}{l}\text { Q 14: I consider this text relevant for my life } \\
\text { and career. }\end{array}$ & 72 \\
\hline
\end{tabular}

Tab. 5: Respondents' critical reading skills and social mediation

Quite surprisingly, only one student indicated more than one option (however, being an international student, he was not included in this study) and no Slovak student commented on the answers provided. This could indicate that the respondents were intimidated by the authority of the test; they did not dare to question the options even though they were encouraged to do so. Table 6 shows the research results related to the importance of the text for the reader and his/her community:

\begin{tabular}{|l|c|}
\hline Descriptor: This text is important because it shows that... & $\begin{array}{c}\text { Respondents } \\
\text { (\%) }\end{array}$ \\
\hline $\begin{array}{l}\text { A-Some reading habits and shopping habits at book markets undergo } \\
\text { changes (correct) }\end{array}$ & 12 \\
\hline B-It criticises the lack of critical thinking of young people & 1 \\
\hline C-It shows the most recent statistics & 78 \\
\hline D-It explains why traditional printed books are not popular any more & 9 \\
\hline E-Other & 0 \\
\hline
\end{tabular}

Tab. 6: Q12: Group results: the importance of the text for the reader and his/her community

More specifically, in Q12, only $12 \%$ of respondents identified the correct option. One student chose option B (the text criticizes the lack of critical thinking of young people), an answer most probably accepted as "general truth" regardless of the text in debate. The distractor D was also obviously incorrect; the text stated traditional books are more popular on the children's and young adult market (the information was mentioned directly in lines 33-34: In the case of the children's and young adult market, the two surveys have shown that printed books are still more popular than e-books.). In this question, 9\% respondents, by selecting the distractor $\mathrm{D}$, un-critically anticipated the higher popularity of e-sources regardless of the information provided by the text. Thus a cumulative sum of $10 \%$ of students displayed a serious lack of critical thinking; they provided answers they felt are somehow generally "true" and did not check their view with the text.

What we find of key importance in this research is the fact that in Q12, as many as 78\% of respondents chose the distractor $C$ (the text shows the most recent statistics). The distractor $C$ was technically correct, however, these students overlooked the fact that the 
extract they were reading did not provide a single date for the statistical surveys discussed. The respondents assumed the reliably-looking statistics mentioned in it were up-to-date and did not try to find and check the sources. We find this an alarming factreaders were overwhelmed by seemingly exact numbers (despite the fact that they were not accompanied by authors and dates of research, and neither did the text state its author or bibliography, features that part and parcel of all professional academic texts). Furthermore, no student added a commentary or withdrew from the options. This proves that the respondents overestimated the authority of the test-they did not consider the idea that the options provided might be incomplete or inaccurate in relation to the text and the questions.

In order to analyse the social strategies and undergraduates' critical thinking, we were also interested in whether they found the selected topic important in general (Q13) and specifically for themselves and their future careers. Therefore, a specific article discussing recent trends in book reading and the rise of e-literature for various age-levels was selected as a research tool. The researchers assumed that future teachers and translators would be interested in this topic, as their future occupation will involve reading, teaching, translating and dealing with books, either printed or e-literature, thus, in Q14, we took answers $\mathrm{A}$ and $\mathrm{B}(\mathrm{A}-\mathrm{I}$ consider this text relevant and important for my future career and life and $\mathrm{B}-\mathrm{I}$ consider this text quite relevant...) to be correct. Interestingly, for this question, $21 \%$ of respondents considered this text relevant and important for their life and future career $(22 \%)$ or quite relevant and important (51\%), however, $25 \%$ did not consider the text directly or indirectly related to their future profession and 3\% found the topic irrelevant. These research results also show a discrepancy between Q14 and Q13, focused on the identification of the overall importance of the topic in the contemporary setting. In Q13, again, we deemed answers A and B to be correct (A-the topic is very important and $\mathrm{B}$ - the topic is quite important, whereas answers $\mathrm{C}$-the topic is not very important and $\mathrm{D}$-the topic is completely unimportant as incorrect). In $\mathrm{Q} 13$, as many as $98 \%$ of respondents considered the topic very important and $2 \%$ quite important; both answers were classified as "correct" by the researchers. Thus, total of $100 \%$ of respondents considered the topic of e-literature generally important, however, $28 \%$ failed to extend this importance from the general sphere to their personal and professional life and well-being.

\section{Discussion}

As we explained in the theoretical part of this study, successful reading at university level in EFL employs academic reading and critical reading skills. These skills require not only the ability to read and comprehend the text but also to go beyond and above the text: the ability to gather (deduce, anticipate, decode) a great deal of information and metainformation about the text and its discourse, identification of assumed author or authors (if not stated) and his or her more or less direct intentions (e.g. to inform, persuade, compare, synthetize). Furthermore, successful academic readers need to master the identification of the genre (if not clearly stated), the number, quality and relevance of references and the numeric data and statistics presented. In questions related to critical thinking, readers were not only to read but also to combine various skills and pieces of information: linguistic (foreign language), general knowledge, their own experience with e-literature and previous knowledge, and many others. Obviously, correct answers to many questions were based on good general reading skills in the L2, but also they required critical reading and thinking and academic reading skills. 
The research results showed that:

1) The whole sample unit mean was 11.87 points ( $\mathrm{SD}=1.426)$; variance 0.05 . Minimum number of points achieved was 8 (53.33\%), maximum was 14 points (93.33\%).

2) Among Slovak undergraduates, there is a significant difference in identification of explicit and implicit information at the significance level of $1 \%$.

3) $94.5 \%$ of Slovak undergraduates can identify explicit information, $76.5 \%$ implicit information and $88 \%$ the main idea of the text.

4) $25 \%$ of Slovak undergraduates could not identify the number of sources based on intext references. $27 \%$ could not make correct assumptions about the author and $17 \%$ could not identify the genre of the academic text.

5) While $100 \%$ considered the topic of e-literature relevant nowadays, $28 \%$ could not see the relevance of reading habits of various age groups of readers, including teenagers and young adults for their future careers as teachers and interpreters/translators. Alarmingly, 78\% failed to find the weak spot (the missing dates of statistics) and thus could not read the text critically.

No similar research has been conducted nationally, however, the research outcomes presented in this study correspond with PISA 2018 which proved that in reading, Slovak 15-year old students scored below the OECD average (gaining 458 points; OECD, 2021) and below several culturally and educationally similar countries (Poland-512, the Czech Republic-485, Hungary-476, Ukraine-466; OECD, 2021).

Our research results also correspond with the 2019 national Maturita state examinations (in the following year the Covid-19 crisis affected the testing procedure). In the 2019 Maturita state examination, the overall reading comprehension of the B1 sample unit was $50.52 \%$ and B2 reading comprehension was $62.7 \%$ (which is substantially lower than our total results, 75.9\%), however, Maturita examination results included all high school in Slovakia, including technical schools where the final scoring is usually lower.

However, the research results obtained are identical to the 2019 Maturita in specific sub-skills: in selective reading (true-false tasks, corresponding to the use of both local and global strategies, defined in subchapter 1 ), total reading results were identical to our total research findings-75.9\%. However, just like in our research results, in the Maturita 2019 students seriously underachieved in global strategies (completing the missing sentence in the text according to the context and general meaning)-reaching only $54.4 \%$ (Krajňáková, Ficek, Kostolanská et al, 2021). In terms of the structure of tasks, the easiest tasks in Maturita 2019 included explicit answers and the main idea (matching of paragraphs and paragraph headings, 91.2\% correct answers compared with our findings-94.5\%). In implicit questions and gap-filling, based on the text read (employing thinking about the overall meaning of the text), only $42.7 \%$ correct answers were gathered (correlation with our research findings was not confirmed); however, even though undergraduates achieved $76.5 \%$ correct answers, they scored lower than in the search for a piece of explicit information.

Internationally, Alavi and Abdollahzadeh (2008) conducted a similar research of reading comprehension of argumentative narrative texts with a sample unit of 115 participants, proving that overall performance on the implicit argumentative texts is more difficult that the other text types and versions (2008, p. 118). Ozono (2002) also found that both of the examined groups gained higher degrees of comprehension in the explicit texts. Similar research has also been conducted at the University of Bedfordshire (Sheraz 2018). Sheraz (2018) summarizes many studies (Ballard, 1996; Ladd \& Ruby, 1999) 
pointing out the importance of the integration of critical reading into the established models or reading used in non-western countries.

The limitations of the presented research are twofold: first, there is no comparable national research done in Slovakia that would allow a comparative study. In 2010, Gavora and Matúšová conducted a similar research, however, they focused on global (i.e. critical) and local strategies in Slovak language only. Nevertheless, their research results correlate with our findings-Slovak undergraduates managed local strategies but underscored in global strategies (Gavora \& Matúšová, 2010). The second limitation of the study lies in a relatively low number of comprehension questions which the researchers plan to extend in ongoing research, employing selected methods of the Watson-Glasner test of critical thinking. Also, the qualitative research will be complemented by qualitative monitored interviews with respondents, monitoring their individual perception of various reading tasks.

Nevertheless, the reading comprehension test used for this study proved to be a good quality tool as a placement test, identifying students' complex reading skills. Attention was paid not only to their EFL reading skills, but also to a broader ability to think about the text, context and its broader meaning. Underachieving students were identified and further personalised attention will be paid to them so that they can improve their reading and thinking performance in the L2 and academically excel.

\section{Conclusion}

The research described herein shows that, in order to become compatible with the international trends in university education in general and specifically in teaching EFL reading skills, tending towards a more critical reading (Sheraz, 2018, Hanesová, 2014), Slovak university education in the field of humanities needs a transformation of teaching methodology towards the cognitive model of reading, integrating aspects of critical and social reading (Kosturková, 2014). Thus, undergraduates displaying acceptable general reading skills but substandard critical skills need to learn to read more effectively and more critically - to be able not only to identify the explicitly mentioned data but also information that is implicit, and further-to make assumptions about the author, the genre of the text, its relevance (e.g. number and quality of referred sources) significance for themselves and their career and well-being as well as the life of their community. That requires an overall shift toward critical pedagogy, implemented into CLIL-formatted subjects. Specifically, Slovak undergraduates in their first year of studies need more guidance in the integration of their general reading skills, critical thinking and academic reading skills in a way that, except for the basic text parameters, will enable them to:

1) Understand the topic thoroughly, think about it in an objective and critical way (e.g. identify the author's intentions)

2) Identify the different arguments there are in relation to a particular issue (e.g. attitudes to the topic of e-books according to various age-levels)

3) Evaluate a point of view to determine how strong or valid it is

4) Recognise any weaknesses or negative points that there are in the evidence or argument (e.g. a missing date, reference, authority of the writer, etc.)

5) Notice what implications there might be behind a statement or argument (e.g. who benefits from the presented data)

6) Provide structured reasoning and support for an argument that might affect their reading performance (based on a Paulian critical framework; 2006, adopted by authors). 
Numerous scholars (e.g. Sartori 1993, Zelenková \& Hanesová, 2019, Židová, 2018; Štefániková 2019) agree that the adoption of the cognitive strategies mentioned in subchapter 1 may contribute to the reduction of so-called cognitive incompetence which refers to the insufficient ability of citizens to completely implement their own important decisions independently and thus, become more independent readers, learners and individuals.

Finally, the critical thinking framework, which is based on best theories and practices certified by the researchers and specialists in this field, is suitable for any discipline and teaching in the field of humanities (Rošteková, 2019). It remains crucial to all students studying in academic courses in English, and to university lecturers, as well. The critical framework, if applied properly, leads to discourse that prevents misunderstanding and leads to increased reading and thinking effectiveness as well as alleviating the tendency towards cognitive and digital incompetence. These skills are transferable to all areas of human life, and thus, may also reduce the inclination to believe in hoaxes, fake news or even adjust one's voting behaviour in a democratic, tolerant and objective way.

\section{Acknowledgements}

This article originated with the support of the project VEGA 1/0437/19 (Cultural and Educational Agency of the Ministry of Education, Science, Research and Sport or the Slovak Republic) entitled The importance of internationalization of university education for the construction of the EU identity and for the increase of competition in the European space.

The article is the outcome of the project VEGA 1/0118/20 (Cultural and Educational Agency of the Ministry of Education, Science, Research and Sport or the Slovak Republic) entitled Dyslexia as a linguistic-cognitive disorder and its symptoms in developing reading literacy in mother and foreign (English) Language.

\section{References}

Alawi, S. M. \& Abdollahzadeh, E. (2008). Explicit/Implicit Signals, Text Types and Reading Comprehension. Pazhuhesh-e Zabanha-ye Khareji, 41(Special issue), 109-126.

Alderson, Ch. J. (2005). Assessing Reading. Cambridge: Cambridge University Press.

Ballard, B. (1996). Through language to learning: Preparing overseas students for studying in western universities. In H. Coleman, Society and the language classroom (pp. 148-168). Cambridge, UK: Cambridge University Press.

Cameron, L. (2001). Teaching Languages to Young Learners. Cambridge: Cambridge University Press.

Carrell, P. L. (1989). Metacognitive awareness and second language reading, Modern Language Journal, 73, 121-133.

Cottrell, S. (2005). Critical Thinking Skills. Developing Effective Analysis and Argument. New York: Palgrave Macmillan.

Ennis, R. H. (2011). Critical Thinking: Reflection and Perspective I. Inquiry, (26)1, 4-18.

Gavora, P. \& Matúšová, P. (2010). Sonda do čitatel'skej gramotnosti vysokoškolských študentov. Pedagogika, 1(3), 183-196.

Gavora, P. (Ed.). (2012). Ako rozvíjat' porozumenie textu u žiaka. Nitra: Enigma.

Grabe, W. \& Stoller, F. L. (2011). Teaching and Researching Reading. Harlow: Pearson Education.

Gura, Radovan. 2005. Práca s odborným písaným textom-Compte Rendu In Z. Hokrová, Sborník př́spěvků z konference Profilingua, (pp. 114-118). Plzeň: Západočeská univerzita. 
Hanesová, D. (2014). From Learning Facts to Learning to Think. Banská Bystrica: PF.

Höhn, E. (2020). Kultúrna identita. In E. Höhn, Mestá a ich príbehy-európska učebnica o kultúrnych tradíciách, (pp. 21-28). Banská Bystrica: DALI BB.

Javorčíková, J. \& Kováč, S. (2018). Motivation to read: facts and myths. Radomskie studia filologiczne. 7(1), 27-36.

Khalifa, H. \& Weir, C. J. (2009). Examining reading: research and practice in assessing second language reading. Cambridge: Cambridge University Press.

Kolečáni-Lenčová, I. (2020). Linguistic Landscape and Reading Comprehension in foreign Language Teaching. AD ALTA : Journal of Interdisciplinary Research, 10(1), 160-164.

Kosturková, M. (2014). Úroveň kritického myslenia študentov odboru Vychovávatel'stvo. Lifelong Learning - celoživotní vzdělávání, 4(1), 45-61. DOI: http://dx.doi.org/10.11118/lifele2014040145.

Krajňáková, D., Ficek, T. Kostolanská, J. et al. (2021). Správa o výsledkoch EČ a PFIČ MS 2019-anglický jazyk úrovne B1, B2, C1. Bratislava: NÚCEM.

Krashen, S. D. \& Terrell, T. D. (1998). The Natural Approach: Language Acquisition in the Classroom. New York: Prentice Hall Europe.

Ladd, P.D. \& Ruby, J.R. (1999). Learning style and adjustment issues of international students. Journal of Education for Business, 74(6), 363-367.

Lipman, M. (1988). Critical Thinking-What Can It Be? Educational Leadership 46(1) 3843. http://www.ascd.org/ASCD/pdf/journals/ed_lead/el_198809_lipman.pdf

Lojová, G. \& Straková, Z. (2012). Teoretické východiská vyučovania angličtiny v primárnom vzdelávaní. Bratislava: Univerzita Komenského.

MacLachlan, G. \& Reid, I. (1994). Framing and Interpretation. Carlton: Melbourne University Press.

McDonough, J. \& Shaw, C. (1993). Materials and Methods in ELT: a teacher's guide. Oxford: Blackwell.

Mistrík, J. (1997). Štylistika. Bratislava: Slovenské pedagogické nakladatel'stvo.

OECD (2021). 21st-Century Readers: Developing Literacy Skills in a Digital World. Available at: https://doi.org/10.1787/a83d84cb-en.

O'Malley, J., Chamot, A. Stewner-Manzanares, G., Kupper, L. \& Russo, R. (1985). Learning strategies used by beginning and intermediate ESL students. Language Learning 35, 21-46.

O'Malley, J. \& Chamot, A. (1990). Learning strategies in Second Language Acquisition. Cambridge: Cambridge University Press.

Ostler, S. (1980). A survey of academic needs for advanced ESL. TEESOL QUATERLY. 14, 489-502.

Oxenden, C. \& Latham-Koenig, Ch. et al. (2001). English File (Upper-intermediate). Oxford: Oxford University Press.

Oxford, R. L. (1990). Language Learning Strategies: What every teacher should know. New York: Newsbury House.

Ozono, S. (2002). An empirical study to the effects of logical connective in EFL reading comprehension. Annual Review of English Language Education in Japan, 13, 61-70.

Paul, R. \& Elder, L. (2006). The Thinker's Guide to The Art of Socratic Questioning. Tomales: The Foundation for Critical Thinking.

Paul, R. (2005). Critical Thinking: What? Why? How? January 6, 2021,

Piršl, D., Popovska, S. \& Stojković, N. (2017). Critical Thinking, Strategic Learning and Metacognition in ESP. The Journal for Teaching English for Specific and Academic Purposes, 5(3), 603-613. 
PISA (2018). Programme for International Student Assessment. Available at: https://www.oecd.org/pisa/PISA-results_ENGLISH.png

Robinson, F. P. (1948). Effective Study. New York: Harper and Bros.

Robertson, D. (1983). English language use, needs and proficiency among foreign students at the University of Illinois in Urban. University of Illinois: Champaign.

Rošteková, Mária. (2019). In search of adequate educational policy for foreign language teaching in Slovakia. XLinguae: European Scientific Language Journal, 12(1XL), 66-81.

Sartori, G. (1993). Teória demokracie. Bratislava: Archa.

Sheraz, S. (2018). Investigating Types of Reading used by Native and Non-native English Readers on Academic Reading: An Eye Tracking Study. Bedfordshire: University of Bedfordshire.

Scholes, R. (1991). Protocols of Reading. New Haven: Yale University Press.

Šipošová, M. (2017). Konštruktivistické aspekty v procese rozvíjania čítania s porozumením ako prostriedok zdokonal'ovania odbornej jazykovej spôsobilosti na ceste ku kompetenciám. In Ž. Balážová, Aplikované jazyky v univerzitnom kontexte IV. (pp. 27-42). Zvolen: Technická univerzita.

Skills You Need (2020). “What is Communication?” Last modified March 1, 2021. Available at: www.skillsyouneed.com/ips/what-is-communication.html

Štefániková, L. (2019). Transformácia politických strán z postdemokratickej perspektívy. In J. Koper, Postdemokracia ako proces hl'adania novej kvality demokracie, (pp. 79-96). Praha: Naše Vojsko.

Straková, Z. \& Cimermanová, I. (2005). Teaching and learning English language. Prešov: Fakulta humanitných a prírodných vied Prešovskej univerzity.

The Literacy Dictionary - The Vocabulary of Reading and Writing

UNESCO (2000). New Approaches to Literacy Learning-A Guide for Teacher Educators Available at: http://www.nzdl.org/cgi-bin/library?e=d-00000-00---off-0cdl--00-0---0-10-0---0---0direct-10---4-------0-0l--11-en-50---20-about---00-0-1-00-0--4----0-011-10-0utfZz-8-00\&cl=CL2.14\&d=HASHef69ab3bea68c3e92bbb2d.4.1\&gt=1

Upson M. (2021). What are Academic Skills? Available at: https://www.practicaladultinsights.com/what-are-academic-skills.htm

Veverková, D. (2020). Rozvíjanie cudzojazyčnej čitatel'skej kompetencie pri práci s odborným textom. Zvolen: Technická Univerita.

Zápotočná, O. (2001). Rozvoj počiatočnej literárnej gramotnosti. In B. Pupala, Predškolská a elementárna pedagogika, (pp. 271-306). Praha: Portál.

Zelenková, A. \& Hanesová, D. (2019). Intercultural Competence of University Teachers: a Challenge for internalisation. JoLaCe. 7(1), 1-18. https://doi.org/10.2478/jolace2019-0001

Židová, D. (2018). Reading between the lines and intercultural communication in contemporary British fiction. In J. Duchovičová, Inovatívne trendy $v$ odborových didaktikách v kontexte požiadaviek praxe, (pp. 313-319). Nitra: PF UKF.

\section{Contact}

doc. PaedDr. Jana Javorčíková, PhD.

Matej Bel University

Faculty of Arts

Tajovského 40

97590 Banská Bystrica, Slovakia

jana.javorčíková@umb.sk 
PhDr. Mária Badinská, PhD.

Matej Bel University

Faculty of Political Science and International Relations

Department of International relations and diplomacy

Kuzmányho 1

97590 Banská Bystrica, Slovakia

maria.badinska@umb.sk

Ing. Lenka Ližbetinová, PhD.

The Institute of Technology and Business in České Budějovice

Faculty of Corporate Strategy

České Budějovice,

Czech Republic

lizbetinova@mail.vstecb.cz

David Brett

University of Sassari

Department of Humanities and Social Sciences

Via Roma 151, 07100 Sassari,

Italy

dbrett@uniss.it 